\title{
Diet of invertebrates sampled in leaf-bags incubated in a tropical headwater stream
}

\author{
Emerson M. de Carvalho ${ }^{1}$ \& Virgínia S. Uieda ${ }^{2,3}$ \\ ${ }^{1}$ Centro de Pesquisa da Biodiversidade, Universidade Estadual de Mato Grosso do Sul. Caixa Postal 351, 79804-970 \\ Dourados, Mato Grosso do Sul, Brasil. E-mail: carvalho.em@gmail.com \\ ${ }^{2}$ Departamento de Zoologia, Universidade Estadual Paulista. Caixa Postal 510, $18618-000$ Botucatu, São Paulo, Brasil. \\ 3 Corresponding author. E-mail: vsuieda@ibb.unesp.br
}

\begin{abstract}
The diet of macroinvertebrates sampled in leaf-bags incubated in a tropical stream was analyzed on a spatial scale (one forested and one deforested area) and on a temporal scale (dry and rainy seasons). The macroinvertebrates were mostly represented by detritivores specialized in fine detritus (69\%), followed by generalist detritivores (10\% with a diet based on fine and coarse detritus), carnivores (10\%), omnivores (8\%), and one detritivore genera specialized on coarse detritus (3\%). The detritivores exhibited a broad spatial and temporal distribution and were represented mainly by Ephemeroptera, Trichoptera and Diptera. Phylloicus sp. (Trichoptera) consumed mostly coarse detritus (CPOM) and can be classified as the unique specialist shredder in this stream. Carnivores were represented by Anacroneuria sp. (Plecoptera), Hetaerina sp. and Heteragrion sp. (two Odonata). Omnivory was observed for Anacroneuria sp. and Smicridea sp. (Trichoptera), which evidently varied spatially and temporally in the proportion of the food consumed. The high diversity and the wide distribution of the taxa that used organic matter as food resource demonstrated the great importance of this food item to the macroinvertebrates community in this tropical stream.
\end{abstract}

KEY WORDS. Detritus; gut content; macroinvertebrates; trophic groups.

Headwater streams are particularly influenced by the riparian vegetation, which provides shade and organic inputs (CUMmins 1973, VANNOTE et al. 1980). The intimate relationship between the stream and its riparian zone constitutes the source of a significant portion of the annual energy input (Cummins 1973, Cummins \& KuUg 1979).

Allochthonous litter is the dominant energy resource for consumers in low-order shaded streams (ABELHO 2001, GraÇA 2001, Dobson 2005). A considerable fraction of the litter entering streams is retained within the channel (Pozo 2005) and becomes available as food resource for the vast majority of detritivores and microbial decomposers (Dobson 2005). This litter can be colonized by a great number of macroinvertebrates (UiEd \& GAJARDO 1996) that can use it not only as food but also as shelter.

Annually, streams receive great quantities of leaf litter (Abelho 2001, Elosegi \& Pozo 2005), an important source of allochthonous organic matter that is assimilated by the aquatic organisms (UiEdA \& MotTA 2007). After entering streams, leaves are subject to physical abrasion, microbial degradation and invertebrate fragmentation (AвELHo 2001, GraçA 2001). These fragmented particles will become part of the fine-particulate organic matter (Cummins 1973), which is ecologically important to populations of collectors inhabiting pounds downstream (Graça 2001, Graça \& Canhoto 2006).

Because of the importance of the detritus chain in lotic ecosystems, promoting the main link between allochthonous inputs and invertebrate and vertebrate secondary consumers, major emphasis has been directed toward the compartmentalization of this food resource (GraçA 2001). A considerable amount of information about the detritus processing in loworder forested streams is available in the literature (e.g. AbelHo 2001). The relationship between this basal resource and the aquatic invertebrates is assessed mainly by gut content studies (Basaguren et al. 2002, Rosi-Marshall \& Wallace 2002, Benstead \& Pringle 2004, Motta \& Uieda 2004, 2005, Cheshire et al. 2005, Lancaster et al. 2005, Albariño \& Villanueva 2006).

According to MotTA \& Uieda (2004), the great importance of invertebrates on the trophic structure of streams contrasts with the scarcity of data in the literature concerning their feeding habits. Therefore, the aim of our study was to analyze the trophic dynamics of a macroinvertebrate community from a tropical headwater stream on spatial and temporal scales. To achieve this, we compared the diet of macroinvertebrates sampled in two consecutive areas of the same stream, one forested and other deforested (spatial scale), on the dry and rainy seasons of 2004 (temporal scale).

\section{MATERIAL AND METHODS}

The study was carried out at the Ribeirão da Quinta stream $\left(23^{\circ} 06^{\prime} 47^{\prime \prime} \mathrm{S}, 48^{\circ} 29^{\prime} 46^{\prime \prime} \mathrm{W}\right)$, located in the municipality of Itatinga, state of São Paulo, southeast Brazil, at an elevation of $743 \mathrm{~m}$ a.s.l. This is a third-order stream (sensu Strahler classifi- 
cation, STANFORD 1996), located in a cattle-raising farm, distant from urban areas. The climate is tropical with two distinguishable seasons: a dry season between June and October and a rainy season between November and May.

Two sections of this stream, with a surface area of about $120 \mathrm{~m}^{2}$ each, were chosen. The first one is shaded by a wellpreserved gallery forest (forested area). The second one is located about $300 \mathrm{~m}$ downstream and is surrounded only by herbaceous vegetation (deforested area). During the experiment, two water parameters were analyzed: water temperature and current velocity.

The study took place during July (dry season) and December 2004 (rainy season). The macroinvertebrates were sampled using leaf-bags incubated on the stream bottom for 13 days. This short colonization period was chosen because we learned from this study and from other studies developed in the same stream (unpublished data) that the invertebrate colonization in this stream is fast, although other data of experimental works about macroinvertebrate communities in tropical streams showed that peaks of invertebrate abundance and biomass occur around 21 days of incubation (CARVALHO \& UIEDA 2004, 2006, Carvalho et al. 2008). Leaf-bags incubated for 21 days were completely decomposed, not remaining macroinvertebrates or leafs after this incubation period. The bags were prepared with a plastic mesh $(20 \times 15 \mathrm{~cm}, 10 \mathrm{~mm}$ mesh size) and were filled with $5.00 \pm 0.05 \mathrm{~g}$ of freshly cut leaves of two plant species: Cabralea canjerana (Vell.) Mart. (Meliaceae), a common tree in the gallery forest area, and Pycreus decumbens T. Koyama (Cyperaceae), an herbaceous plant common in the deforested area. The leaves were cut off from the tree branches (green leaves) due to the great presence of green leaves entering the stream. The leaf-bags (10 of each plant species, installed in both areas and during both seasons) were attached to the stream bottom with the aid of fishing weights. The bags were removed after the incubation period, placed into a plastic container and transported to the laboratory in an icebox.

In the laboratory, the leaves were rinsed with distilled water over three granulometric sieves (GRANUTEST 1.00, 0.50, and $0.25 \mathrm{~mm}$ mesh sizes). The sieves were inspected under stereomicroscope for the sorting of the macroinvertebrates, which were preserved in 70\% alcohol for subsequent identification and gut content analysis. The animals were identified to the highest possible taxonomic level (PenNaK 1978, Lopretto \& TelL 1995, Merritt \& Cummins 1996, Fernández \& Domínguez 2001, Costa et al. 2004, 2006 Olifiers et al. 2004) and counted. In order to estimate the relative area used by each macroinvertebrate taxon when colonizing the leaves, the number of grid squares occupied by each taxon was determined using a graduate slide, according to Ribeiro \& Uieda (2005).

The diet was determined for all taxa that achieved values of abundance and area higher than $1 \%$ on each season and stream area, except for Chironomidae larvae. As has been pointed out by some authors (Nessimian \& Sanseverino 1998,
Nessimian et al. 1999, Henriques-Oliveira et al. 2003, Motta \& UiEDA 2004), this family shows a wide diet variation with genera belonging to different trophic groups. Because of this high diet flexibility it would be necessary to identify Chironomidae larvae until genera level for a correct diet analysis. However, it was not possible to do this in the present study.

Ten animals of each taxon and treatment (season and stream area) were dissected. Their guts were extracted and analyzed under a stereomicroscope and a microscope. Gut contents were classified into four categories: coarse detritus (coarseparticulate organic matter or CPOM), fine detritus (fine-particulate organic matter or FPOM), filamentous and unicellular algae, and animal tissue. The classifying of coarse and fine detritus was done visually, based on particle size and structure (vegetal cells visible in the coarse detritus). The area (number of grid squares) occupied by each food type was measured using a graduated slide. The relative area (\%) covered by each food type was used to assign the taxa to one of the three trophic groups: 1) detritivores consuming CPOM and FPOM, 2) carnivores preying on animals, 3) omnivores consuming resources from two or more food categories. The herbivorous trophic group was not considered due to the origin of the material consumed; only decomposing leaf litter.

Although the macroinvertebrates were sampled in leafbags of two plant species, the diet analysis of each taxon showed no differences related to the leaf species used. Thus, this variable was not considered and differences in diet were analyzed only according to the season and stream area where taxa were sampled.

To visualize the seasonal and spatial organization of the macroinvertebrates relative to their diet we used the Bray-Curtis dissimilarity measure to perform a cluster analysis, using the program Biodiversity Professional version 2 (MCAleece 2004).

\section{RESULTS}

Data of rainfall and air temperature (Fig. 1) evidenced that the sampling months were good representatives of the dry (July) and rainy (December) seasons at this area. Low values of air and water temperatures were registered during July (Figs 1 and 2), the dry season. Also, the months with higher rainfall were the ones with higher values of current velocity, two times faster in the deforested area than in the forested one (Fig. 2).

The macroinvertebrates sampled in leaf-bags resulted in a total of 5,826 specimens belonging to 22 families, represented mostly by seven orders of aquatic insects (Tab. I). During the dry season, Diptera, mostly Chironomidae larvae, was the dominant taxon, representing more than 50\% of the abundance (Tab. II, Fig. 3). During the rainy season, Trichoptera was the dominant order in the deforested area, while Ephemeroptera was the dominant order in the forested area (Tab. III, Fig. 3). The number of taxa represented by more than $1 \%$ of abundance and occupied area, and then used for diet analysis (except Chironomidae), varied between seasons and areas: 11 in the 

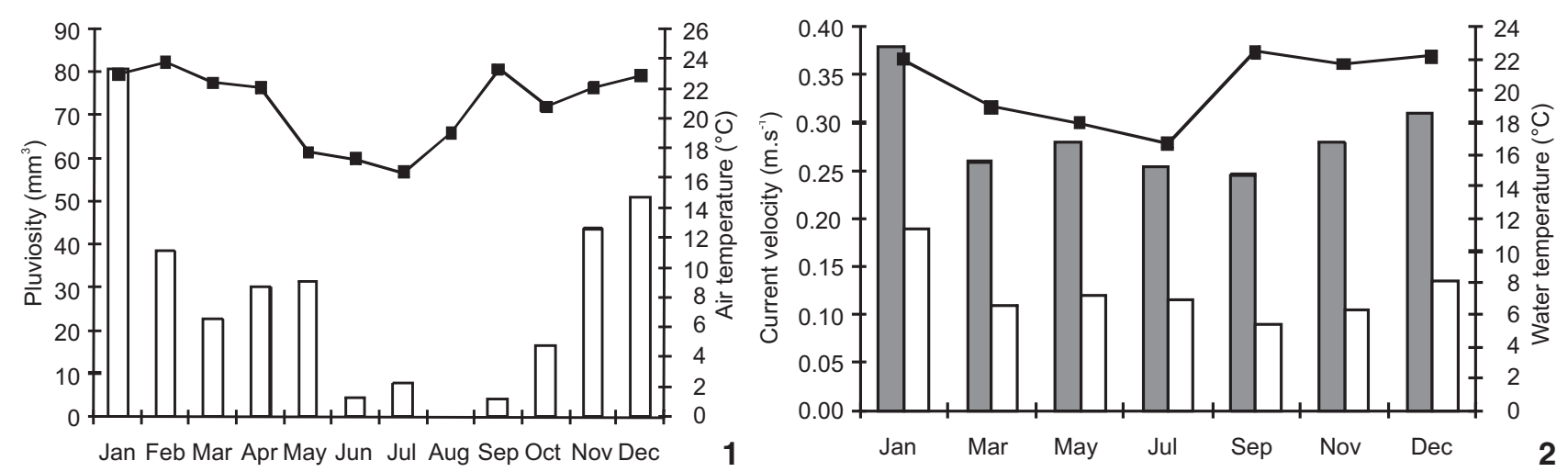

Figures 1-2. Abiotic data of the studied area measured during 2004: (1) mean values of rainfall (white bars; average of the month) and air temperature (black line; average of the month), (2) water temperature (black line; value of the sampling day) and current velocity (black bars for Deforested area and white bars for Forested area; values of the sampling day). Source of weather data: CIIAGRO (www.ciiagro.sp.gov.br), measured at a station distant $50 \mathrm{~km}$ from the stream.

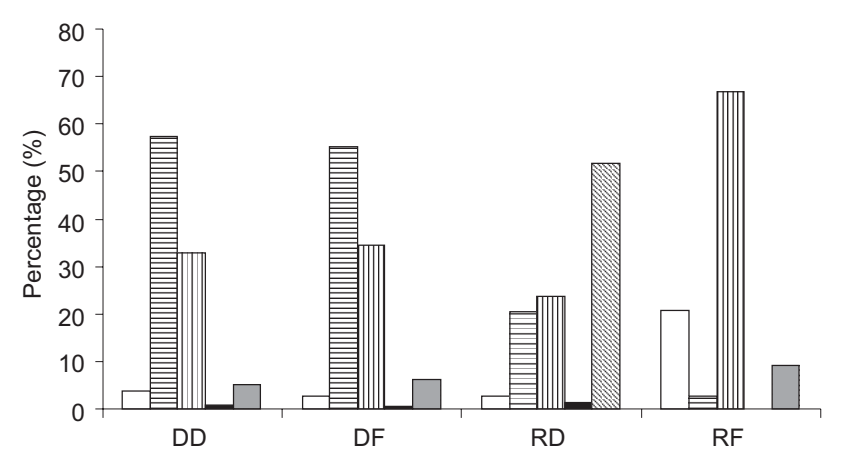

$\square$ Coleoptera 目Diptera 四Ephemeroptera $\square$ Plecoptera $\square$ Trichoptera

Figure 3. Relative abundance (\%) of the most abundant insect orders sampled in leaf-bags incubated in the Ribeirão da Quinta stream. (DD) dry season-deforested area, (DF) dry season-forested area, (RD) rainy season-deforested area, (RF) rainy season-forested area.

dry season-deforested area, 10 in the dry season-forested area, 17 in the rainy season-deforested area, and 11 in the rainy season-forested area (Tabs II and III).

Fine detritus was the main food category consumed by the macroinvertebrates in Ribeirão da Quinta stream, with few exceptions (Fig. 4). This food resource was the only food ingested by most taxa or, in some cases, was the main food consumed in association with coarse detritus, animal tissue, or algae. The four taxa found on both seasons and stream areas (Ancylidae, Heterelmis Sharp, 1882, Traverhyphes Molineri, 2001 and Farrodes Peters, 1971) showed feeding specialization in fine detritus. The Trichoptera Phylloicus Müller, 1880 fed mainly on coarse detritus and was sampled mainly in the forested area. Animal tissue was consumed mostly by two Odonata genera and by the Plecoptera Anacroneuria Klapálek, 1909 (Fig. 4). This last taxon showed spatial variation on diet consuming fine detritus and animal material in a similar amount in the forested area (dry season) and mainly animal material in the deforested area (dry and rainy seasons). Algae were not consumed alone and were found always in low percentages in the gut contents.

Five groups were defined after analyzing the dissimilarity in the taxa diet (Fig. 5). The trophic group of detritivores that consumed predominantly or exclusively fine detritus (Group I) was the most representative in the two areas and seasons and comprised $69 \%$ of the analyzed taxa. The last $31 \%$ formed four groups composed by carnivores that consumed mainly or exclusively animal tissue (Group II - 10\%), omnivores consuming two or more resources, including animal tissue (Group III - 8\%), detritivores that consumed fine and coarse detritus in a similar amount (Group IV - 10\%), and one detritivore genus specialized on coarse detritus (Group V - 3\%).

\section{DISCUSSION}

The macroinvertebrates community sampled in leaf-bags was composed mostly by Insecta, represented by seven orders, which are normally found associated to leaf litter (CRISCI-BisPo et al. 2007). Considering the diverse taxonomic groups that comprise the stream macroinvertebrates community, none has been more studied than the aquatic insects. These are frequently the most abundant macroinvertebrates collected in stream benthic samples and are taxonomically and functionally diverse (HAUER \& RESH 1996).

Several recent papers have demonstrated that invertebrates associated to leaves may use them as food resource and/ or shelter (Carvalho \& Uieda 2004, 2006, Ribeiro \& Uieda 2005, CRISCI-BISPO et al. 2007). It is important to recognize that leaves can protect and influence the availability of trophic resources for benthic macroinvertebrates (CALLisTo et al. 2001, CRISCI-BISPO et al. 2007). A benthic community similar to that of the present 
Table I. Macroinvertebrates sampled in leaf-bags incubated in the Ribeirão da Quinta stream, during the dry (July 2004) and rainy (December 2004) seasons.

\begin{tabular}{|c|c|}
\hline Mollusca - Gastropoda & Arthropoda - Insecta (continued) \\
\hline Ancylidae & Heteroptera \\
\hline Lymnaeidae & Pleidae \\
\hline Arthropoda - Crustacea - Decapoda & Neoplea Esaki \& China, 1928 \\
\hline Aeglidae & Odonata \\
\hline Aegla castro Schmidt, 1942 & Calopterygidae \\
\hline Arthropoda - Insecta & Hetaerina Selys, 1853 \\
\hline Coleoptera & Megapodagrionidae \\
\hline Elmidae & Heteragrion Selys, 1862 \\
\hline Heterelmis Sharp, 1882 & Plecoptera \\
\hline Gyrinidae & Gripopterygidae \\
\hline Diptera & Tupiperla Froehlich, 1969 \\
\hline Chironomidae & Perlidae \\
\hline Empididae & Anacroneuria Klapálek, 1909 \\
\hline Simuliidae & Trichoptera \\
\hline Simulium lutzianum Pinto, 1932 & Calamoceratidae \\
\hline Ephemeroptera & Phylloicus Müller, 1880 \\
\hline Baetidae & Glossosomatidae \\
\hline Americabaetis Kluge, 1992 & Protoptila Banks, 1904 \\
\hline Baetodes Needham \& Murphy, 1924 & Hydropsychidae \\
\hline Caenidae & Smicridea McLachlan, 1871 \\
\hline Caenis Stephens, 1835 & Hydroptilidae \\
\hline Leptohyphidae & Neotrichia Morton, 1905 \\
\hline Traverhyphes Molineri, 2001 & Ochrotrichia Mosely, 1934 \\
\hline Tricorythopsis Traver, 1958 & Hydroptila Dalman, 1819 \\
\hline Leptophlebiidae & Leptoceridae \\
\hline Farrodes Peters, 1971 & Nectopsyche Müller, 1879 \\
\hline Meridialaris Peters \& Edmunds, 1972 & Juveniles * \\
\hline Juveniles * & \\
\hline
\end{tabular}

*Early stages of juveniles not identified to genus level.

work was also found by CarvalHo \& Uieda $(2004,2006)$, CarvalHo et al. (2008) and Ribeiro \& UIEDA (2005) that analyzed the benthic macroinvertebrates associated to the rocky substratum of the Ribeirão da Quinta stream. In this sense, it may be over-simplistic to assume that all invertebrates collected from litter are feeding specifically on the leaves (Boulton \& Boon 1991). According to CRISCI-BISPO et al. (2007), many insects sampled on leaf litter must have used the litter only as substratum, redistributing themselves among the rocks and leaves.

Fine-particulate organic matter (FPOM) was the most abundant food resource found in the gut contents of the macroinvertebrates from the Ribeirão da Quinta stream, classified as detritivores, specialists or generalists. MotTa \& UiEdA (2004) also found particulate organic matter in the diet of most aquatic insects of a tropical stream. It has been suggested that detritus has the potential to maintain systems with a great diversity of species (e.g. Rosemond et al. 1998, Moore et al. 2004). High species richness, a great availability of detritus as food resource and a high number of detritivorous species was also found in the epiphytic compartment of a tropical stream of the same basin of Ribeirão da Quinta (MotTA \& UiEDA 2005). In some cases, the fine detritus was also found associated with other resources, as coarse-particulate organic matter and algae.

When the main ingested food is coarse detritus, the detritivorous consumer is usually classified in the functional group of shredder (MerRitT \& Cummins 1996). In this sense, the Trichoptera Phylloicus sp. is the only one that could be classified as shredder in this study. Some works suggest that shred- 
Table II. Macroinvertebrates sampled in leaf-bags incubated in two areas of the Ribeirão da Quinta stream during the dry season (July 2004). Absolute $(\mathrm{n})$ and relative (Ab\%) abundance, absolute $\left(\mathrm{mm}^{2}\right)$ and relative (Oa\%) occupied area.

\begin{tabular}{|c|c|c|c|c|c|c|c|c|}
\hline \multirow{2}{*}{ Taxa } & \multicolumn{4}{|c|}{ Deforested area } & \multicolumn{4}{|c|}{ Forested area } \\
\hline & $\mathrm{n}$ & $\mathrm{Ab} \%$ & $\mathrm{~mm}^{2}$ & $\mathrm{Oa} \%$ & $\mathrm{n}$ & $\mathrm{Ab} \%$ & $\mathrm{~mm}^{2}$ & $\mathrm{Oa} \%$ \\
\hline \multicolumn{9}{|l|}{ Mollusca } \\
\hline Ancylidae & 26 & 2 & 73 & 2 & 28 & 3 & 85 & 4 \\
\hline \multicolumn{9}{|l|}{ Coleoptera } \\
\hline Heterelmis & 62 & 4 & 99 & 3 & 27 & 3 & 35 & 2 \\
\hline \multicolumn{9}{|l|}{ Diptera } \\
\hline Chironomidae & 849 & 50 & 723 & 21 & 545 & 53 & 492 & 22 \\
\hline Empididae & 5 & $<1$ & 9 & $<1$ & 1 & $<1$ & 1 & $<1$ \\
\hline Simuliidae & 95 & 6 & 163 & 5 & 6 & 1 & 13 & 1 \\
\hline \multicolumn{9}{|l|}{ Ephemeroptera } \\
\hline Americabaetis & 201 & 12 & 527 & 15 & 24 & 2 & 46 & 2 \\
\hline Baetodes & 87 & 5 & 192 & 5 & - & - & - & - \\
\hline Traverhyphes & 172 & 10 & 434 & 12 & 234 & 23 & 492 & 22 \\
\hline Farrodes & 74 & 4 & 360 & 10 & 85 & 8 & 396 & 17 \\
\hline Meridialaris & 1 & $<1$ & 24 & $<1$ & - & - & - & - \\
\hline Juveniles * & 8 & $<1$ & 9 & $<1$ & 4 & $<1$ & 2 & $<1$ \\
\hline \multicolumn{9}{|l|}{ Heteroptera } \\
\hline Neoplea & - & - & - & - & 7 & $<1$ & 21 & $<1$ \\
\hline \multicolumn{9}{|l|}{ Odonata } \\
\hline Hetaerina & 4 & $<1$ & 43 & 1 & 4 & $<1$ & 100 & 4 \\
\hline \multicolumn{9}{|l|}{ Plecoptera } \\
\hline Tupiperla & 1 & $<1$ & 12 & $<1$ & 3 & $<1$ & 13 & $<1$ \\
\hline Anacroneuria & 14 & 1 & 421 & 12 & 4 & $<1$ & 117 & 5 \\
\hline \multicolumn{9}{|l|}{ Trichoptera } \\
\hline Phylloicus & 1 & $<1$ & 67 & 2 & 4 & $<1$ & 389 & 17 \\
\hline Protoptila & 2 & $<1$ & 30 & $<1$ & - & - & - & - \\
\hline Smicridea & 47 & 3 & 236 & 7 & - & - & - & - \\
\hline Neotrichia & 10 & 1 & 16 & $<1$ & 59 & 6 & 74 & 3 \\
\hline Ochrotrichia & 7 & $<1$ & 13 & $<1$ & - & - & - & - \\
\hline Hydroptila & 17 & 1 & 44 & 1 & - & - & - & - \\
\hline Nectopsyche & 1 & $<1$ & 4 & $<1$ & - & - & - & - \\
\hline Juveniles * & 2 & $<1$ & 1 & $<1$ & - & - & - & - \\
\hline Total & 1686 & & 3503 & & 1038 & & 2275 & \\
\hline
\end{tabular}

* Early stages of juveniles not identified to genus level.

ders are scarce in tropical streams (DOBSON et al. 2002, UIEDA \& MoтTA 2007), and most of the common shredder taxa from temperate streams is not present in the tropics (Rosemond et al. 1998, CHeshire et al. 2005). Also, other works showed the occurrence of shredders in tropical streams, but in low density (CAllisto et al. 2001, Callisto et al. 2004, Gonçalves JR et al. 2006). Moreover, shredding invertebrates may be less important in tropical streams because there are alternative decomposition pathways for leaves, such as faster microbial processing due to higher temperatures (Boulton \& Boon 1991, Abelho 2001, Mathuriau \& Chauvet 2002, Uieda \& MotTa 2007).

The specialist shredder Phylloicus sp. showed a limited distribution and occurs mainly in the forested area of the Ribeirão da Quinta stream. As discussed by Benstead \& Pringle (2004), some 
Table III. Macroinvertebrates sampled in leaf-bags incubated in two areas of the Ribeirão da Quinta stream during the rainy season (December 2004). Absolute ( $\mathrm{n})$ and relative (Ab\%) abundance, absolute $\left(\mathrm{mm}^{2}\right)$ and relative (Oa\%) occupied area.

\begin{tabular}{|c|c|c|c|c|c|c|c|c|}
\hline \multirow{2}{*}{ Taxa } & \multicolumn{4}{|c|}{ Deforested area } & \multicolumn{4}{|c|}{ Forested area } \\
\hline & $n$ & $\mathrm{Ab} \%$ & $\mathrm{~mm}^{2}$ & $\mathrm{Oa} \%$ & $\mathrm{n}$ & $A b \%$ & $\mathrm{~mm}^{2}$ & Oa\% \\
\hline \multicolumn{9}{|l|}{ Mollusca } \\
\hline Ancylidae & 64 & 3 & 128 & 3 & 269 & 22 & 354 & 8 \\
\hline Lymnaeidae & 8 & $<1$ & 68 & 2 & 22 & 2 & 78 & 2 \\
\hline \multicolumn{9}{|l|}{ Crustacea } \\
\hline Aeglidae & 1 & $<1$ & 132 & 3 & 3 & $<1$ & 193 & 4 \\
\hline \multicolumn{9}{|l|}{ Coleoptera } \\
\hline Heterelmis & 48 & 2 & 67 & 1 & 134 & 11 & 174 & 4 \\
\hline Gyrinidae & - & - & - & - & 5 & $<1$ & 10 & $<1$ \\
\hline \multicolumn{9}{|l|}{ Diptera } \\
\hline Chironomidae & 322 & 18 & 165 & 4 & 233 & 18 & 184 & 4 \\
\hline Empididae & 44 & 2 & 31 & 1 & - & - & - & - \\
\hline Simuliidae & 1 & $<1$ & 1 & $<1$ & - & - & - & - \\
\hline \multicolumn{9}{|l|}{ Ephemeroptera } \\
\hline Americabaetis & 170 & 9 & 657 & 15 & 4 & $<1$ & 18 & $<1$ \\
\hline Caenis & 1 & $<1$ & 4 & $<1$ & 2 & $<1$ & 10 & $<1$ \\
\hline Traverhyphes & 138 & 7 & 419 & 10 & 211 & 17 & 527 & 12 \\
\hline Tricorythopsis & 5 & $<1$ & 23 & $<1$ & 1 & $<1$ & 2 & $<1$ \\
\hline Farrodes & 47 & 3 & 232 & 5 & 68 & 6 & 313 & 7 \\
\hline Juveniles * & 64 & 3 & 28 & 1 & 158 & 13 & 85 & 2 \\
\hline \multicolumn{9}{|l|}{ Hemiptera } \\
\hline Neoplea & - & - & - & - & 1 & $<1$ & 2 & $<1$ \\
\hline \multicolumn{9}{|l|}{ Odonata } \\
\hline Hetaerina & 3 & $<1$ & 128 & 3 & 1 & $<1$ & 3 & $<1$ \\
\hline Heteragrion & - & - & - & - & 4 & $<1$ & 237 & 5 \\
\hline \multicolumn{9}{|l|}{ Plecoptera } \\
\hline Anacroneuria & 26 & 1 & 440 & 10 & - & - & - & - \\
\hline \multicolumn{9}{|l|}{ Trichoptera } \\
\hline Phylloicus & 2 & $<1$ & 38 & 1 & 53 & 4 & 2259 & 50 \\
\hline Protoptila & 14 & $<1$ & 208 & 5 & - & - & - & - \\
\hline Smicridea & 247 & 13 & 594 & 14 & 1 & $<1$ & 2 & $<1$ \\
\hline Neotrichia & 3 & $<1$ & 3 & $<1$ & 58 & 5 & 50 & 1 \\
\hline Ochrotrichia & 90 & 5 & 145 & 3 & - & - & - & - \\
\hline Hydroptila & 292 & 16 & 658 & 15 & 1 & $<1$ & 3 & $<1$ \\
\hline Nectopsyche & 1 & $<1$ & 14 & $<1$ & 1 & $<1$ & 15 & $<1$ \\
\hline Juveniles * & 280 & 15 & 122 & 3 & 1 & $<1$ & 1 & $<1$ \\
\hline Total & 1871 & & 4303 & & 1231 & & 4518 & \\
\hline
\end{tabular}

* Early stages of juveniles not identified to genus level.

of the negative impacts of deforestation on sensitive taxa could be reduced by the maintenance of vegetated riparian zones. Shredders and collectors are considered the major primary consumers in forested streams, providing the main link between the organic inputs and the predatory invertebrates (CHEsHIRE et al. 2005). How- ever, these primary consumers (leaf specialists) are often microendemic and particularly vulnerable to deforestation (Cummins \& Klug 1979, Benstead \& Pringle 2004, Baxter et al. 2005).

For Albariño \& Villanueva (2006), the hydraulic conditions and the food availability were responsible for a higher 

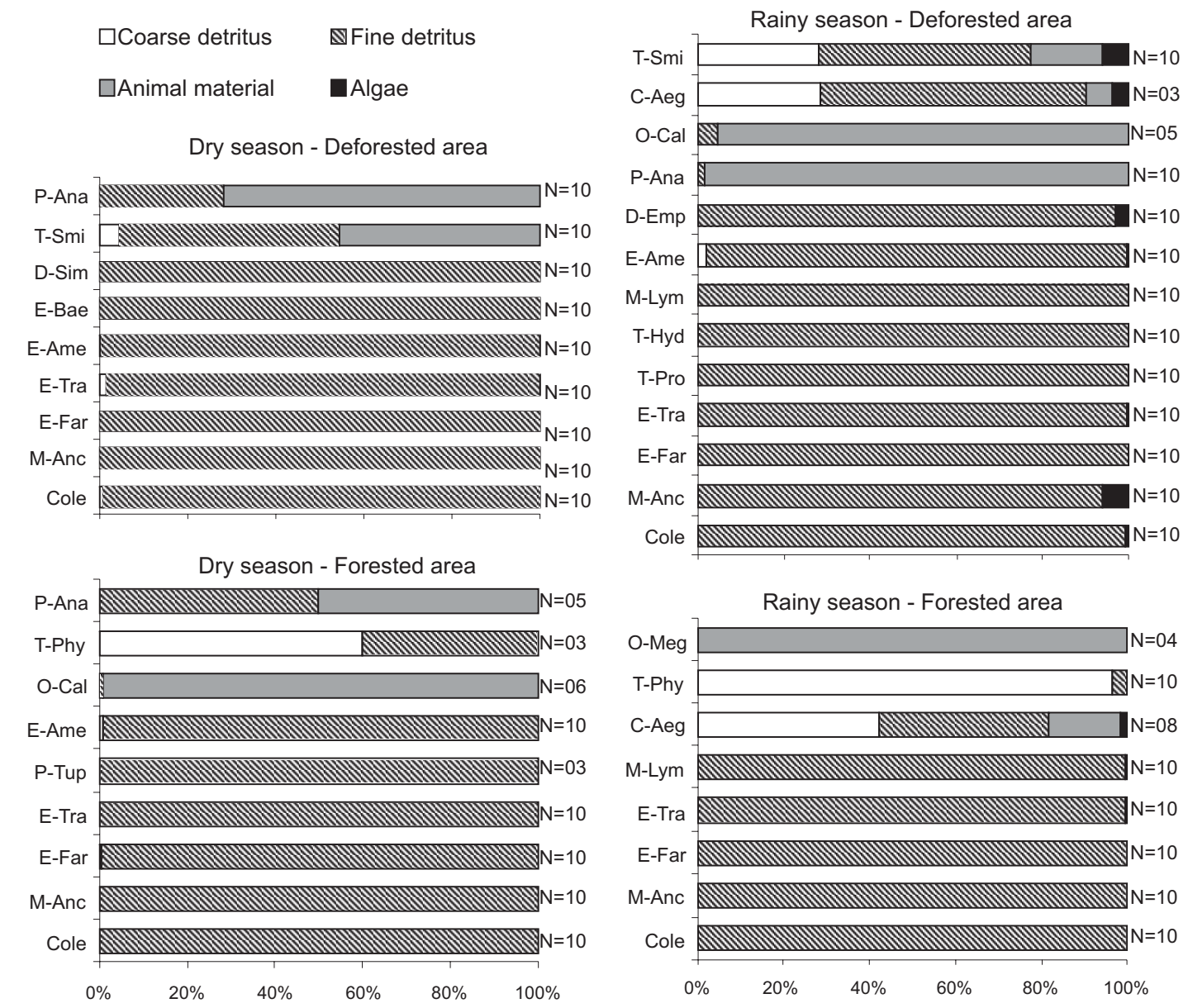

Figure 4. Diet composition (percentage of each food type in the gut contents) of the invertebrates sampled in leaf-bags incubated in the Ribeirão da Quinta stream, during the dry (July 2004) and rainy (December 2004) seasons and at two areas. (C-Aeg) Crustacea-Aegla castro, (Cole) Coleoptera-Heterelmis, (D-Emp) Diptera-Empididae, (D-Sim) Diptera-Simuliidae, (E-Ame) Ephemeroptera-Americabaetis, (E-Bae) Ephemeroptera-Baetodes, (E-Far) Ephemeroptera-Farrodes, (E-Tra) Ephemeroptera-Traverhyphes, (M-Anc) Mollusca-Ancylidae, (M-Lym) Mollusca-Lymnaeidae, (O-Cal) Odonata-Hetaerina, (O-Meg) Odonata-Heteragrion, (P-Ana) Plecoptera-Anacroneuria, (P-Tup) Plecoptera-Tupiperla, (T-Hyd) Trichoptera-Hydroptila, (T-Phy) Trichoptera-Phylloicus, (T-Pro) Trichoptera-Protoptila, (T-Smi) TrichopteraSmicridea. $\mathrm{N}=$ number of dissected individuals that presented some material in the gut.

density of the plecopteran Klapopteryx kuscheli Illies, 1960, a specialist shredder. In the same way, our results suggest that food availability (high leaf litter availability in the forested area) and stream retentiveness (high leaf litter standing stock during the rainy season) are suitable habitat traits to Phylloicus. According to Pozo et al. (1997), the phenology of litter input and discharge regime may be responsible for the temporal litterfall variation. In a stream of the same basin of Ribeirão da Quinta, UiedA \& KiKUCHI (1995) and AFonso et al. (2000) found that the litterfall peak occurred in the early wet season (September and October). In an Atlantic Rain Forest stream, RezENDE \& Mazzoni (2005) also determined a peak of litter input during the rainy season (October, December and February).
Some macroinvertebrates consumed algae associated to fine detritus, or also to coarse detritus and animal material, but always in small amount and never alone. The animals that fed on a combination of algae, organic matter and microbiota by scraping submerged rocks or macrophytes are classified by some authors as periphyton feeders (UIEDA et al. 1997, МотTA \& UiEDA 2004). However, the trophic group of periphyton feeders used for fishes by UIEDA et al. (1997), for macroinvertebrates by MotTa \& Uieda (2004), and which correspond to herbivores and detritivores of the functional feeding group of scrapers by Merritt \& Cummins (1996), was not used here due to the low proportion of algae consumed. Thus, we decided to keep the definition of generalist detritivores for these consumers. 


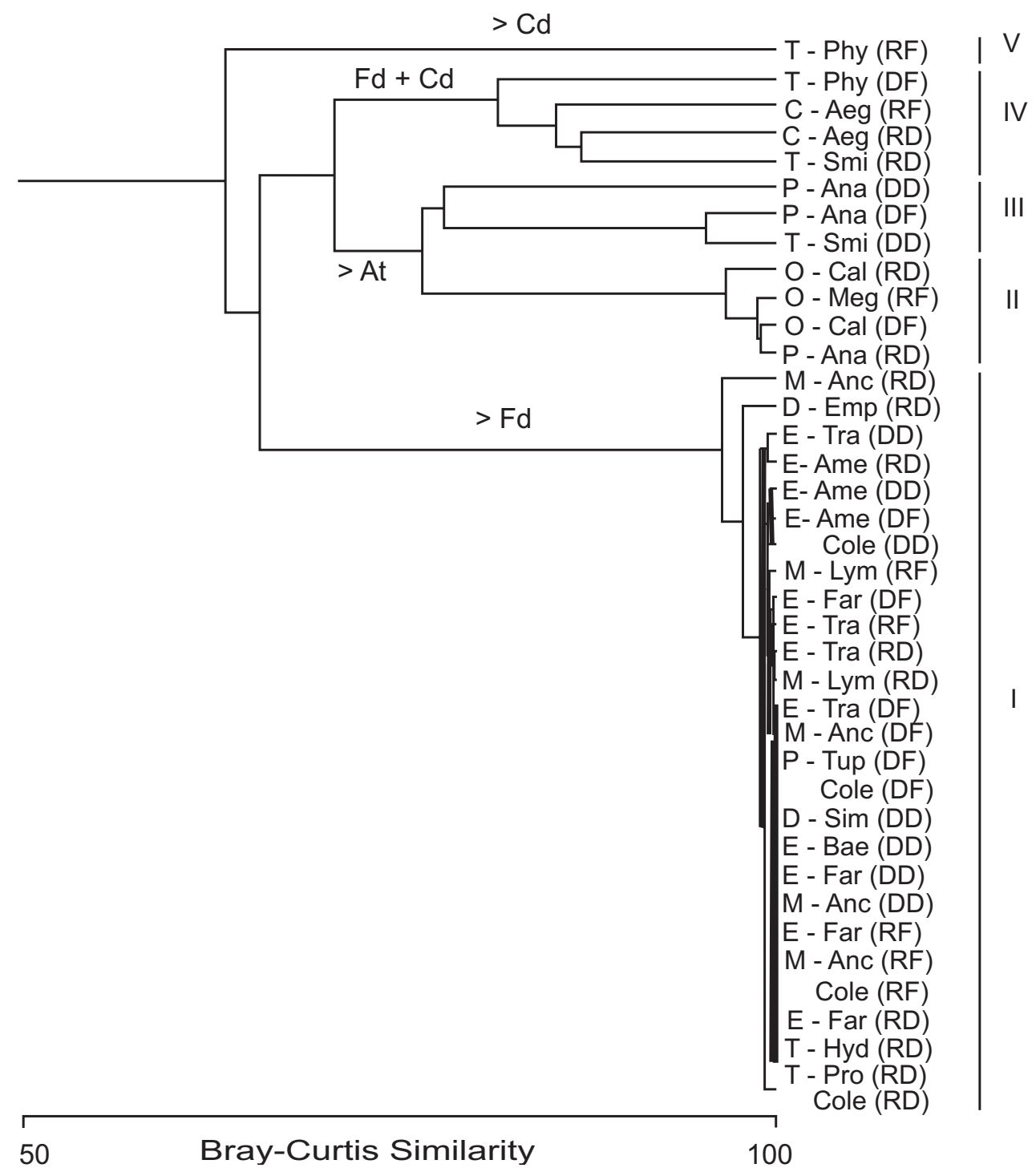

Figure 5. Dendrogram of similarity grouping 39 macroinvertebrates taxa based on diet data. Taxa that consumed mainly coarse detritus $(>\mathrm{Cd})$, fine and coarse detritus $(\mathrm{Fd}+\mathrm{Cd})$, mainly animal tissue $(>\mathrm{At})$, and mainly fine detritus ( $>\mathrm{Fd})$. (C-Aeg) Crustacea-Aegla castro, (Cole) Coleoptera-Heterelmis, (D-Emp) Diptera-Empididae, (D-Sim) Diptera-Simuliidae, (E-Ame) Ephemeroptera-Americabaetis, (E-Bae) Ephemeroptera-Baetodes, (E-Far) Ephemeroptera-Farrodes, (E-Tra) Ephemeroptera-Traverhyphes, (M-Anc) Mollusca-Ancylidae, (M-Lym) Mollusca-Lymnaeidae, (O-Cal) Odonata-Hetaerina, (O-Meg) Odonata-Heteragrion, (P-Ana) Plecoptera-Anacroneuria, (P-Tup) PlecopteraTupiperla, (T-Hyd) Trichoptera-Hydroptila, (T-Phy) Trichoptera-Phylloicus, (T-Pro) Trichoptera-Protoptila, (T-Smi) Trichoptera-Smicridea, (RF) rainy season-forested area, (RD) rainy season-deforested area, (DF) dry season-forested area, (DD) dry season-deforested area. For explanation about the groups classification (I to $\mathrm{V}$ ) sees the text.

The three genera of carnivores (one genus of Plecoptera and two of Odonata) found in the Ribeirão da Quinta stream were polyphagous with respect to their animal prey and, according to LANCASTER et al. (2005), this is a common characteristic of many other predator insects. MotTA \& UiEDA (2004) also observed carnivory among the Odonata genera, which reduced the feeding overlap by consuming different insect orders, the same strategy used by the carnivorous genera found at the Ribeirão da Quinta stream. Hetaerina Selys, 1853 consumed Ephemeroptera (Americabaetis Kluge, 1992 and juveniles of early stages) and Trichoptera. Heteragrion Selys, 1862 consumed mainly Diptera (Chironomidae) and smaller amounts of early develop- 
mental stages of Ephemerotera. The diet of Anacroneuria sp. was based mainly on Chironomidae, and on smaller amounts of Trichoptera (Smicridea McLachlan, 1871 and Glossosomatidae) and of Ephemeroptera (juveniles of early developmental stages).

True omnivory (mixing plants and animals in the diet) is common among terrestrial and marine arthropods, but poorly documented in freshwater systems (LANCASTER et al. 2005). The only two genera showing true omnivory in the Ribeirão da Quinta stream, Smicridea and Anacroneuria, were the most representative genera of Trichoptera and Plecoptera orders respectively.

Although the diet of Chironomidae larvae was not analyzed in this work, it is important to emphasize that this insect group has an important role in the food webs of aquatic communities. Fine particulate organic matter (FPOM) is the main food item used by chironomids, but always associated with other food resources (Henriques-Oliveira et al. 2003, MotTa \& Uieda 2004, Callisto et al. 2007, SANSEverino \& Nessimian 2008, SiLva et al. 2008). However, it is important to recognize that chironomids, such as most aquatic insects, are not limited to a single feeding strategy (MotTa \& Uieda 2004). Due to their potential flexibility in diet and great dominance on the stream community, a future taxonomic and dietary analysis of the chironomids found at this stream will be persuading.

The groups that were collected in both dry and rainy seasons presented low temporal variation in the diet, possibly due to the constant offer of a variety of food supplies for the community. A minor seasonal change in functional feeding groups was also found by MotTa \& Uieda (2004), who related this to constant food resource availability. The seasonal dietary changes involved mostly a modification in the proportion of food items consumed, results also found by MotTA \& UIEDA (2004). The spatial analysis also showed similarity in the diet of animals sampled on the forested and deforested areas, reinforcing the trophic structure stability of the studied macroinvertebrates community. But it is also important to emphasize that the methodology used to sample the macroinvertebrates (litter bags that enable sampling macroinvertebrates that are used to live associated to leaves, independent if they use leaves as food resource or shelter) could be also responsible for the low temporal and spatial variation in the diet.

In general, we identified five dietary groups: I) generalist detritivores consuming fine detritus associated with coarse detritus and/or algae; II) specialist detritivores feeding mainly on fine detritus; III) detritivores specialized on coarse detritus; IV) specialist carnivores consuming aquatic insects; and V) omnivores feeding on animal and vegetal tissues. Together, the specialist and the generalist detritivores represented $82 \%$ of the taxa sampled in leaf-bags, followed by the carnivores and omnivores that represented together $18 \%$ of the studied macroinvertebrates.

According to Minuc (1997), in stream systems the generalist habit is a common strategy among primary consumers of the detrital chain. This study corroborates the recent literature (Rosi-Marshall \& Wallace 2002, Benstead \& Pringle 2004, Moore et al. 2004, Motta \& Uieda 2004, Baxter et al. 2005, Cheshire et al. 2005, Lancaster et al. 2005, Albariño \& Villanueva 2006) that emphasizes the great importance of organic matter as food resource for the macroinvertebrates community. However, the high diversity of the macrofauna associated to litter compared to the low diversity of shredders suggests that the coarse particulate organic matter is used more as substrate than as direct food, becoming an important food source to macroinvertebrates after its decomposition until fine particles.

\section{ACKNOWLEDGEMENTS}

The authors thank Hamilton A. Rodrigues and Michelé O.D. Corrêa for assistance in the field. The first author was supported by a scholarship from the Brazilian National Research Council (CNPq). We also thank the valuable comments of two anonymous referees.

\section{LITERATURE CITED}

Abelho, M. 2001. From litterfall to breakdown in streams: a Review. The Scientific World 1: 656-680.

Afonso, A.A.O.; R. Henry \& R.C.S.M. Rodella. 2000. Allochthonous matter input in two different stretches of a headstream (Itatinga, São Paulo, Brazil). Brazilian Archives of Biology and Technology 43 (3): 335-343.

Albariño, R.J. \& V.D. Villanueva. 2006. Feeding ecology of two plecopterans in low order Andean-Patagonian stream. International Review of Hydrobiology 91 (2): 122-135.

Basaguren, A.; P. Riaño \& J. Pozo. 2002. Life history patterns and dietary changes of several caddisfly (Trichoptera) species in a northern Spain stream. Archiv für Hydrobiologie 155 (1): 23-41.

BaXter, C.V.; K.D. Fausch \& W.C. SAunders. 2005. Tangled webs: reciprocal flows of invertebrate prey link stream and riparian zones. Freshwater Biology 50 (2): 201-220.

Benstead, J.P. \& C.M. Pringle. 2004. Deforestation alters the resource base and biomass of endemic stream insects in eastern Madagascar. Freshwater Biology 49 (4): 490-501.

Boulton, A.J. \& P.I. Boon. 1991. A review of methodology used to measure leaf litter decomposition in lotic environments: time to turn over an old leaf? Australian Journal of Marine and Freshwater Research 42 (1): 1-43.

Callisto, M.M.; P. Moreno \& F.A.R. Barbosa. 2001. Habitat diversity and benthic functional trophic groups at Serra do Cipó, Southeast Brazil. Revista Brasileira de Zoologia 61 (2): 259-266.

Callisto, M.; M. Goulart; A.O. Medeiros; P. Moreno \& C.A. Rosa. 2004. Diversity assesment of benthic macroinvertebrates, yeasts, and microbiological indicators along a longitudinal gradient in Serra do Cipó, Brazil. Brazilian Journal of Biology 64 (4): 743-755.

Callisto, M.; J.F. Gonçalves Jr \& M.A.S. Graça. 2007. Leaf litter is a possible source for chironomids (Diptera) in Brazilian 
and Portuguese headwater streams. Revista Brasileira de Biologia 24 (2): 442-448.

Carvalho, E.M. \& V.S. Uieda. 2004. Colonização por macroinvertebrados bentônicos em substrato artificial e natural em um riacho de serra de Itatinga, São Paulo, Brasil. Revista Brasileira de Zoologia 21 (2): 287-293.

Carvalho, E.M. \& V.S. Uieda. 2006. Colonization routes of benthic macroinvertebrates in a stream in southeast Brazil. Acta Limnologica Brasiliensia 18 (4): 367-376.

Carvalho, E.M.; V.S. Uieda \& R.L. Motta. 2008. Colonization of rocky and leaf pack substrates by benthic macroinvertebrates in a stream in southeast Brazil. Bioikos 22 (1): 37-44.

Cheshire, K.; L. Boyero \& R.G. Pearson. 2005. Food webs in tropical Australian streams: shredders are not scarce. Freshwater Biology 50 (5): 748-769.

Costa, C.; S. IdE \& C.E. SimonKA. 2006. Insetos imaturos: metamorfose e identificação. Ribeirão Preto, Holos, 249p.

Costa, J.M.; L.O.I. SouZA \& B.B. OldrinI. 2004. Chave para identificação das famílias e gêneros das larvas conhecidas de Odonata do Brasil: comentários e registros bibliográficos (Insecta, Odonata). Publicações Avulsas do Museu Nacional 99: 1-44.

Crisci-Bispo, V.L.; P.C. Bispo \& C.G. Froehlich. 2007. Ephemeroptera, Plecoptera and Trichoptera assemblages in litter in a mountain stream of the Atlantic Rainforest from Southeastern Brazil. Revista Brasileira de Zoologia 24 (2): 545-551.

Cummins, K.W. 1973. Trophic relations of aquatic insects. Annual Review of Entomology 18: 183-206.

Cummins, K.W. \& M.J. KLug. 1979. Feeding ecology of stream invertebrates. Annual Review of Ecology and Systematics 10: $147-172$.

Dobson, M. 2005. Manipulation of stream retentiveness, p. 1924. In: M.A.S. Graça, F. Bärlocher \& M.O. Gessner (Eds.). Methods to study litter decomposition: a practical guide. Netherlands, Spring Publications, X+329p.

Dobson, M.; A. Magana; J.M. Матноoкo \& F.K. Ndegwa. 2002. Detritivores in Kenyan highland streams: more evidence for the paucity of shredders in the tropics? Freshwater Biology 47: 909-919.

Elosegi, A. \& J. Pozo. 2005. Litter input, p. 3-11. In: M.A.S. GraÇA, F. Bärlocher \& M.O. Gessner (Eds.). Methods to study litter decomposition: a practical guide. Netherlands, Spring Publications, $\mathrm{X}+329 \mathrm{p}$.

FERNÁNDEZ, H.R. \& E. DOMINGUEz. 2001. Guía para la determinación de los artrópodos bentónicos sudamericanos. Tucumán, Universidad Nacional de Tucumán, Facultad de Ciencias Naturales e Instituto M. Lillo, VII+282p.

Gonçalves Jr, J.F.; J.S. França; A.O. Medeiros; C.A. Rosa \& M. Callisto. 2006. Leaf breakdown in a tropical stream. International Review of Hydrobiology 91 (2): 164-177.

Graça, M.A.S. 2001. The role of invertebrates on leaf litter decomposition in stream: a Review. International Review of Hydrobiology 86 (4-5): 383-393.
Graça, M.A.S. \& C. Canhoto. 2006. Leaf litter processing in low order streams. Limnetica 25 (1-2): 1-10.

HaUer, F.R. \& V.H. Resh. 1996. Benthic macroinvertebrates, p. 339-369. In: F.R. Hauer \& G.A. Lamberti (Eds). Methods in Stream ecology. San Diego, Academic Press, IX+674p.

Henriques-Oliveira, A.L.; J.L. Nessimian \& L.F.N. Dorvillé. 2003. Feeding habits of Chironomid Larva (Insecta: Diptera) from a stream in the Floresta da Tijuca, Rio de Janeiro, Brazil. Brazilian Journal of Biology 63 (2): 269-281.

Lancaster, J.; D.C. Bradley; A. Hogan \& S. Waldron. 2005. Intraguild omnivory in predatory stream insects. Journal of Animal Ecology 74 (4): 619-629.

Lopretto, E.C. \& G. TelL. 1995. Ecosistema de aguas continentales: metodologias para su studio. Argentina, Ediciones Sur, 1460p.

McAleece, N. 2004. Biodiversity Professional 2.0. The Natural History Museum and the Scottish Association for Marine Science. Avalaible online at: http://www.nhm.ac.uk/ zoology/bdpro [Accessed: X/2007]

Mathuriau, C. \& E. Chauvet. 2002. Breakdown of leaf litter in a neotropical stream. Journal of the North American Benthological Society 21 (3): 384-396.

Merrit, R.W. \& K.W. Cummins. 1996. An introduction to the aquatic insects of North America. Duduque, Kendal/Hunt, XIII+862p.

Minuc, T.B. 1997. The functional trophic role of lotic primary consumers: generalist versus specialist strategies. Freshwater Biology 37 (2): 455-462.

Moore, J.C.; E.L. Berlow; D.C. Coleman; P.C. Ruiter; Q. Dong; A. Hastings; N.C. Johnson; K.S. McCann; K. Melville; P.J. Morin; K. Nadelhoffer; A.D. Rosemond; D.M. Post; J.L. SABo; K.M. Scow; M.J. Vanni \& D.H. Wall. 2004. Detritus, trophic dynamics and biodiversity. Ecology Letters 7 (7): 584-600.

MotTA, R.L. \& V.S. UiedA. 2004. Diet and trophic groups of an aquatic insect community in a tropical stream. Brazilian Journal of Biology 64 (4): 809-817.

MotTA, R.L. \& V.S. UiedA. 2005. Food web structure in a tropical stream ecosystem. Austral Ecology 30 (1): 58-73.

Nessimian, J.L. \& A.M. Sanseverin. 1998. Trophic functional categorization of the chironomid larvae (Diptera: Chironomidae) in first-order stream at the mountain region of Rio de Janeiro State, Brazil. Verh International Verein Limnology 26: 2115-2119.

Nessimian, J.L.; A.M. Sanseverino \& A. Oliveira. 1999. Relações tróficas de larvas de Chironomidae (Diptera) e sua importância na rede alimentar em um brejo de dunas no Estado do Rio de Janeiro. Revista Brasileira de Entomologia 43: 47-53.

Olifiers, M.H.; L.F.M. Dorvillé; J.L. Nessimian \& N. Hamada. 2004. A key to Brazilian genera of Plecoptera (Insecta) based on nymphs. Zootaxa 651: 1-15.

Pennak, R.W. 1978. Fresh-water invertebrates of the United States. New York, Wiley-Intescience, XV+803p. 
Pozo, J.; E. González; J.R. Díez; J. Molinero \& A. Elósegi. 1997. Inputs of particulate organic matter to streams with different riparian vegetation. Journal of the North American Benthological Society 16 (3): 602-611.

Pozo, J. 2005. Coarse particulate organic matter budgets, p. 4350. In: M.A.S. Graça, F. Bärlocher \& M.O. Gessner (Eds). Methods to study litter decomposition: a practical guide. Netherlands, Spring Publications, X+329p.

Rezende, C.F. \& R. Mazzoni. 2005. Seasonal variation in the input of allochthonous matter in na Atlantic Rain Forest stream, Ilha Grande-RJ. Acta Limnologica de Brasiliensia 17 (2): 167-175.

Ribeiro, L.O. \& V.S. Uieda. 2005. Estrutura da comunidade de macroinvertebrados bentônicos de um riacho de serra em Itatinga, São Paulo, Brasil. Revista Brasileira de Zoologia 22 (3): 613-618.

Rosemond, A.D.; C.M. Pringle \& A. Ramérez. 1998. Macroconsumer effects on insect detritivores and detritus processing in a tropical stream. Freshwater Biology 39 (3): 515-523.

Rosi-Marshall, E.J. \& B. Wallace. 2002. Invertebrate food webs along a stream resource gradient. Freshwater Biology 47 (1): 129-142.

Sanseverino, A.M. \& J.L. Nessimian. 2008. The food of larva Chironomidae (Inseca, Diptera) in submerged litter in a forest stream of the Atlantic Forest (Rio de Janeiro, Brazil).
Acta Limnologica Brasiliensia 20 (1): 15-20.

Silva, F.L.; D.C. Moreira; G.L. BochinI \& S.S. RuIz. 2008. Hábitos alimentares de larvas de Chironomidae (Insecta: Diptera) do córrego Vargem Limpa, Bauru, SP, Brasil. Biotemas 21 (2): $155-159$.

STANFORD, J.A. 1996. Landscapes and catchments basins, p. 322. In: F.R. Hauer \& G.A. LAmberti (Eds.). Methods in Stream ecology. San Diego, Academic Press, IX+674p.

Uieda, V.S. \& I.C.S.M. Gajardo. 1996. Macroinvertebrados perifíticos encontrados em poções e corredeiras de um riacho. Naturalia 21: 31-47.

UiEDA, V.S. \& R.M. KiKUCHI. 1995. Entrada de material alóctone (detritos vegetais e invertebrados terrestres) num pequeno curso de água corrente na cuesta de Botucatu, São Paulo. Acta Limnologica Brasiliensis 7 (1): 105-114.

Uieda, V.S.; P. Buzzato \& R.M. Kikuchi. 1997. Partilha de recursos alimentares em peixes em um riacho de serra do Sudeste do Brasil. Anais da Academia Brasileira de Ciências 69: 243-252.

Uieda, V.S. \& R.L. Motta. 2007. Trophic organization and food web structure of southeastern Brazilian streams: a review. Acta Limnologica Brasiliensis 19 (1): 15-30.

Vannote, R.L.; G.W. Minshall; K.W. Cummins; J.R. Sedell \& C.E. Cushing. 1980. The river continuum concept. Canadian Journal of Fisheries and Aquatic Science 37: 130-137.

Submitted: 11.II.2009; Accepted: 03.XII.2009.

Editorial responsibility: Neusa Hamada 